高周波駆動正弦波コンバータの設計法

学生員 池 上 延 宏 (東京工芸大学)
学生員 荒 井 聖 (東京工芸大学)
正 員 中 野 博 民 (東京工芸大学)
正 員 難 波 江 章 (東京工芸大学)

\title{
Design of High Frequency Driven Converter with Sinusoidal Input Current
}

Nobuhiro Ikegami,Student Member,Sei Arai,Student Member,

Hirotami Nakano,Member,Akira Nabae,Member

(Tokyo Institute of Polytechnics)

キーワード : 波形改善、高周波駆動、コンテンサ分割方式、小型軽量化

1.はじめに

先に、回路構成が簡単で制御が容易な新規な正弦波コン バータが提案された。そして、その正弦波コンバータを用 いることにより、高い入力力率が得られるだけでなく、入 力電流波形が効果的に改善されることが明らかとなった(1) (2)。

しかしながら、その正弦波コンバータの設計方法は、未 だ明確化されていない。

そこで、本論文では、その設計法を示すと共に、高周波 化により提案の正弦波コンバータの小型軽量化を達成す 万。

\section{2. 基本原理}

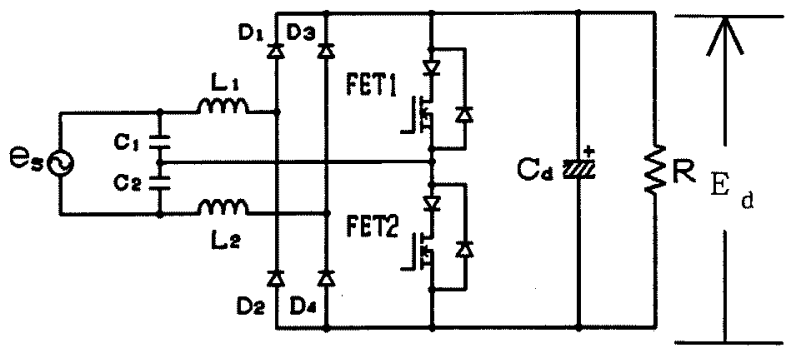

(上図に㧅いて $\mathrm{L}=\mathrm{L}_{1}=\mathrm{L}_{2} 、 \mathrm{C}=\mathrm{C}_{1}=\mathrm{C}_{2}$ )

図 1 回路構成

Fig.1.Proposed circuit configuration.

図 1 に本装置の回路構成を示す。本装置は電源電圧をコ ンデンサで分止し、系統に直列に接続したリアクトルと直

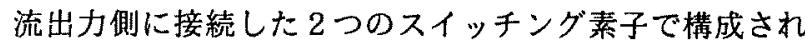
る。またスイッチング素子にMOS F E Tを用い、電源周 波数に比べ遥かに高い周波数で交互にオン、オフを繰り返
す。本装置の出力直流電流理論式は (1) 式となる (3)。た だし、電源電圧を $\mathrm{e}_{\mathrm{S}}=\mathrm{E}_{\mathrm{S}} \mathrm{S}$ i n $\theta(\mathrm{t})$ 、出力直流電圧を $\mathrm{E}_{\mathrm{d}}$ 、昇圧比を $\alpha=\mathrm{E}_{\mathrm{d}} / \mathrm{E}_{\mathrm{S}} 、 \mathrm{~T}_{\mathrm{sw}}$ をスイッチング周期と する。

$$
I_{d}=\frac{E_{S} T_{S W}}{4 \pi L} \int_{0}^{\frac{\pi}{2}} \frac{\operatorname{Sin}^{2} \theta}{2 \alpha-\operatorname{Sin} \theta} d \theta
$$

\section{L C 設計法}

本装置の系統に直列に接続したリアクトル $\mathrm{L}_{1} 、 \mathrm{~L}_{2}$ と電 源電压を分圧する分割コンデンサ $C_{1} 、 C_{2}$ は図 2 に示す手 順で設計する。リアクトル $\mathrm{L}_{1} 、 \mathrm{~L}_{2}$ のインダクタンスは負 荷の電圧及び電流を决め、スイッチング素子の性能と効率 の兼合いからスイッチング周波数 $\mathrm{f}$ swを決定することに よって（2）式より設計する。

$$
L=\frac{T_{S W} E_{d}}{4 \pi I_{d} \alpha} \int_{0}^{\frac{\pi}{2}} \frac{\operatorname{Sin}^{2} \theta}{2 \alpha-\operatorname{Sin} \theta} d \theta
$$

（2）式の積分式は昇圧比 $\alpha$ の関数となるので（3）式 のように置き換えることができる。

$$
L=\frac{T_{S W}}{4 \pi} \frac{E_{d}}{I_{d}} G(\alpha)
$$


従って、（3）式よりスイッチング周波数を高くする程 リアクトルを小型軽量化できる。また、 $G(\alpha)$ は (4) 式の ようになり、図 3 に示すように非線形関数である。

$$
\begin{aligned}
G(\alpha)= & -\left(\pi+\frac{1}{\alpha}\right) \\
+ & \frac{8 \alpha}{\sqrt{4 \alpha^{2}-1}}\left\{\operatorname{Tan}^{-1} \frac{-1+2 \alpha}{\sqrt{4 \alpha^{2}-1}}\right. \\
& \left.-\operatorname{Tan}^{-1} \frac{-1}{\sqrt{4 \alpha^{2}-1}}\right\} \ldots .
\end{aligned}
$$

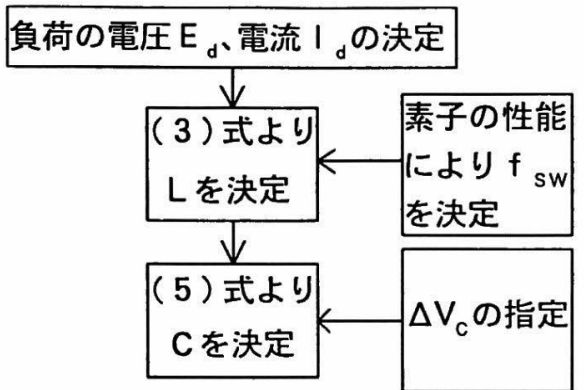

図 2 設計法

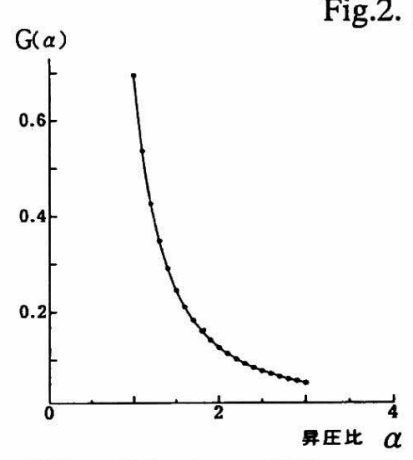

図 $3 G(\alpha)-\alpha$ 特性 図 4

Fig.3. Characteristic of $\mathrm{G}(\alpha)$.

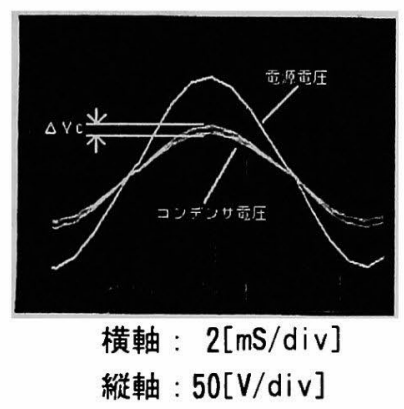

分割コンデンサ電圧波形 Fig.4. Capacitor voltage waveform.
また、分割コンデンサC ${ }_{1} 、 \mathrm{C}_{2}$ のキャパシタンスは、 （5）式より設計する。但し、（5）式のnはコンデンサ の両端の電圧 $V_{\mathrm{c}}$ とコンデンサの充放電によるリプル分電压 $\Delta \mathrm{V}_{\mathrm{c}}$ との比 $\mathrm{V}_{\mathrm{c}} / \Delta \mathrm{V}_{\mathrm{c}}$ を示す。

$$
C=\frac{T_{s W}^{2}}{4 L}\left\{\frac{1}{\operatorname{Cos}^{-1}\left(1-\frac{1}{n}\right)}\right\}^{2} \ldots . .
$$

以上の設計法に基づき、回路の設計例を示す。

まず、電源電圧を $e_{S}=100 \sqrt{2} \operatorname{Sin} \theta(t)[V]$ とし、負荷の 直流出力電圧 $\mathrm{E}_{\mathrm{d}}{ }^{\prime}=150[\mathrm{~V}]$ 、出力直流電流 $\mathrm{I}_{\mathrm{d}}=0.6[\mathrm{~A}]$ とす る。また、スイッチング周波数を $100[\mathrm{kHz}]$ とすると（3） 式よりリアクトルのインダクタンスは $\mathrm{L}_{1}=\mathrm{L}_{2}=120[\mu \mathrm{H}]$
となる。そしてコンデンサのキャパシタンスは、リプル分 電圧 $\Delta \mathrm{V}_{\mathrm{c}}$ を分割コンデンサの両端の電圧の最大値の $20 \%$ 之 なるように $\mathrm{n}=\mathrm{V}_{\mathrm{c}} / \Delta \mathrm{V}_{\mathrm{c}}$ をにに設定すると、（5）式より $\mathrm{C}_{1}=\mathrm{C}_{2}=0.4[\mu \mathrm{F}]$ となる。設計したこれらの回路定数によ り測定した電源電圧と分割コンデンサ電圧波形を図 4 に示 す。図より設計どうりの結果を得ている。

このように、L C の值を簡単に設計できる。

\section{4. おわりに}

先に発表された回路構成が簡単で制御が容易な新規な整 流回路において、明確な設計法を示した。また、高周波駆 動することにより回路が小型化できることを示した。

(平成6年2月25日受付)

\section{文 献}

（1）荒井 聖・中野博民・難波江章：「正弦波コンバー夕」、平成 5 年電気学会産業応用全国大会、p p. $407 \sim 410$

（2）荒井 聖・中野博民・難波江章：「新しい単相人力電流正弦波 整流回路の解析」、電気学会半導体電力変換研究会資料、S P C - 9 $3-67,71$ (平成 5 年 10 月)

（3）池上延宏- 荒井 聖-中野博民・難波江章：「高周波駆動正弦 波コンバー夕」、S P C - 94-17 (平成6 年 1月)

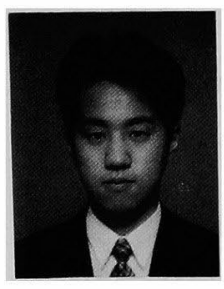

\section{池上 延宏 （学生員）}

昭和 45 年 4 月 7 日生。平成元年 3 月長 野県立赤穂高等学校卒業。同 2 年東京工芸 大学工学部電子工学科入学。現在に至る。

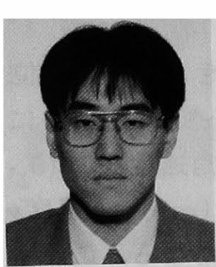

\section{荒井 聖 （学生員）}

昭和 43 年 12 月 24 日生。平成 4 年 3 月東京工芸大学工学部電子工学科卒業。同 年 4 月同大学院工学研究科電子工学専攻修 士課程入学。現在に至る。

中野 博民（正員）

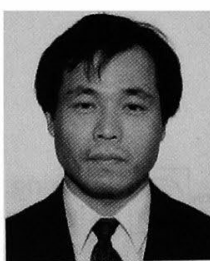

昭和 32 年 7 月 31 日生。同 55 年 3 月 長岡技術科学大学電子機器工学課程卒業。 同 57 年 3 月同大学院工学研究科修士課程 修了。同 62 年 3 月名古屋大学大学院工学 研究科博士課程修了。平成 5 年東京工芸大 学助手。工学博士。半導体電力変換器の研究に従事。

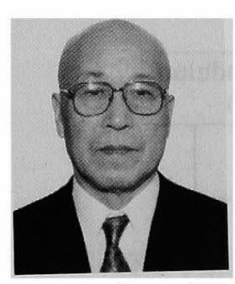

難波江 章 （正員）

大正 13 年 9 月 13 日生。昭和 22 年 9 月東京大学電気工学科卒業。同 26 年 9 月 (株) 東芝入社。同 58 年 4 月長岡 技術科学大学教授。平成 2 年東京工芸大 学教授。工学博士。

IEEE Fellow. 昭和 60 年、平成 3 年電気学会論文賞。' 91 IEEE-IAS Tr.Paper Award. 平成 5 年電気学会業績賞。 